\title{
Nitrogen fertilization in banana grown on a highly weathered soil of the humid mountain region of Puerto Ríco ${ }^{1,2}$
}

\author{
Héber Irizarry, ${ }^{3}$ Ricardo Goenaga ${ }^{4}$ and Ulises Chardón ${ }^{5}$
}

J. Agric. Univ. P.R. 86(1-2):15-26 (2002)

\begin{abstract}
A 40-month experiment was conducted to re-evaluate the nitrogen fertilization recommendation for banana grown on a clayey, mixed isohyperthermic Aquic Haplohumults under rainfed conditions. Five nitrogen rates ( 0 , $85,170,255$ and $340 \mathrm{~kg} / \mathrm{ha} / \mathrm{crop}$ ) were arranged in a randomized complete block design with three replications. The nitrogen treatments were applied with $24.4 \mathrm{~kg} / \mathrm{ha}$ of phosphorus, $651.7 \mathrm{~kg} / \mathrm{ha}$ of potassium, and a minor element mixture containing $22.7 \mathrm{~kg} / \mathrm{t}$ of fertilizer. Treatments were applied every three months. Applications of magnesium alone were also applied between treatments at the rate of $55 \mathrm{~kg} / \mathrm{ha}$ in the plant crop (PC) and $110 \mathrm{~kg} / \mathrm{ha}$ in each of two ratoon crops (R1, R2). During growth and development of three crops we collected data of plant and bunch traits, green and oven-dry biomass weight, nitrogen concentration in various plant organs, and bunch marketable weight at harvest. Results showed that the rate $\times$ crop interaction was highly significant $(P \leq 0.01)$ for total nitrogen uptake, and for nitrogen concentration in the leaf-lamina four months before bunch harvest, and significant $(P \leq 0.05)$ for total dry matter production. Total nitrogen uptake, leaf nitrogen concentration, and total dry matter production linearly increased with increments in the nitrogen rates. Overall total nitrogen uptake and total dry matter production were always significantly higher in the R2 than in the PC. Regardless of the nitrogen rate, a significantly higher nutrient concentration was always found in the leaf-lamina of the R1 plants than in either the PC or the R2 plants. Crop had no significant effect on yield, but nitrogen rate significantly influenced yield. A maximum yield of $57,060 \mathrm{~kg} /$ ha/crop was obtained with an estimated nitrogen application of $240 \mathrm{~kg} / \mathrm{ha}$. This amount corresponded to a leaf nitrogen concentration of between 2.75 and $2.85 \mathrm{~g} / \mathrm{kg}$. Since the maximum yield for all crops was obtained with a $\mathrm{ni}-$ trogen application of only $240 \mathrm{~kg} / \mathrm{ha}$, we concluded that the linear response to fertilization in excess of this amount for total nitrogen uptake, nutrient concentration, and total dry matter production may be attributed to luxury consumption of nitrogen.
\end{abstract}

${ }^{1}$ Manuscript submitted to Editorial Board 6 March 2002.

${ }^{2}$ This paper covers work carried out cooperatively between the Agricultural Research Service-USDA and the Agricultural Experiment Station, University of Puerto Rico. The authors are grateful to Nicolás Díaz, Agricultural Research Technician, for his assistance in conducting the experiment.

${ }^{3}$ Research Horticulturist, Tropical Agriculture Research Station, 2200 Pedro Albizu Campos Ave., Suite 201, Mayagüez, PR 00680-5470.

${ }^{4}$ Research Plant Physiologist, Tropical Agriculture Research Station, Mayagüez, PR.

${ }^{5}$ Chemist, Tropical Agriculture Research Station, Mayagüez, PR. 
Key words: Banana, nitrogen, fertilization, luxury consumption, eroded soil

\section{RESUMEN}

Fertilización con nitrógeno en guineo sembrado en un suelo altamente meteorizado de la zona húmeda de Puerto Rico

Se evaluaron cinco niveles de nitrógeno $(0,85,170,255$ y $340 \mathrm{~kg} / \mathrm{ha} / \mathrm{co}$ secha) en guineos sembrados en un suelo Ultisol típico de la zona montañosa durante un periodo de $\mathbf{4 0}$ meses. Para el estudio se utilizó un diseño de bloques completos al azar con tres repeticiones. Los tratamientos de nitrógeno se aplicaron conjuntamente con $24.4 \mathrm{~kg} / \mathrm{ha}$ de fósforo, $651.7 \mathrm{~kg} / \mathrm{ha}$ de potasio y una mezcla de elementos menores conteniendo $22.7 \mathrm{~kg} / \mathrm{t}$ de abono. Además, entre los tratamientos, las plantas recibieron aplicaciones sencillas de magnesio a las dosis de $55 \mathrm{~kg} / \mathrm{ha}$ en la plantilla (PC) y $110 \mathrm{~kg} / \mathrm{ha}$ en cada uno de los retoños (R1 y R2). Durante el crecimiento y desarrollo de tres cosechas se recopilaron datos de rasgos de la planta y el racimo, peso verde y seco de biomasa, contenido de nitrógeno en los diferentes órganos de la planta y peso mercadeable del racimo a la cosecha. Los resultados demostraron una interacción significativa entre nivel de nitrógeno $\times$ cosecha para la extracción total de nitrógeno, contenido de ese nutrimento en la lámina de la hoja cuatro meses antes de la cosecha, y la producción total de materia seca. Aunque la respuesta a nitrógeno de estos atributos fue lineal, la magnitud del efecto dependió de la cosecha. Excepto para la extracción de nitrógeno en el tratamiento cero, la extracción total de nitrógeno y la producción total de materia seca siempre fueron significativamente altas en el R2 cuando se compararon con el PC. En todos los niveles de nitrógeno, el contenido del nutrimento siempre fue superior en las plantas del R1 que en las plantas del PC o el R2. La cosecha no tuvo efecto significativo sobre el peso mercadeable de los racimos, pero los niveles de nitrógeno afectaron significativamente el rendimiento. El rendimiento máximo alcanzado por cosecha fue de $57,060 \mathrm{~kg} / \mathrm{ha}$ con la aplicación estimada de $240 \mathrm{~kg} / \mathrm{ha}$ de nitrón geno. Esta cantidad del nutrimento está relacionada con un contenido de nitrógeno en la hoja de entre 2.75 a $2.85 \mathrm{~g} / \mathrm{kg}$. Basándonos en que el rendimiento máximo por cosecha se obtuvo con $240 \mathrm{~kg} / \mathrm{ha}$ de nitrógeno, se concluye que la respuesta lineal a abonamiento observada para los atributos de extracción total de nitrógeno, contenido foliar del nutrimento y producción total de materia seca pudieran estar relacionados con el consumo excesivo de nitrógeno.

\section{INTRODUCTION}

Second only to potassium, nitrogen is the most used nutrient in plant growth and development and fruit production. In banana, regardless of cultivars, soils, and climate, the total amount of nitrogen taken up by the plant is closely related to total dry matter production (Lahav, 1995). Other than by using the nutrient for growth, the banana plant cannot store nitrogen. Therefore, this nutrient is considered to be in short supply even when the crop is grown on highly fertile soils (Robinson, 1996).

Visual nitrogen deficiency symptoms in banana are stunted plant growth, leaf-lamina showing a pale-green color, and the leaf-midrib, petiole and sheath showing a reddish-pink coloration. Deficiency symptoms can be easily corroborated by plant tissue analysis (Turner and 
Barkus, 1974). A $2.6 \mathrm{~g} / \mathrm{kg}$ or less nitrogen concentration in the lamina of the third uppermost youngest leaf at the time of bunch emergence is considered a critical level (Lahav and Turner, 1983).

Excess nitrogen in banana promotes pseudostem elongation which results in plant lodging and consequently yield loss. An oversupply of nitrogen increases the time needed for banana fruit filling and affects fruit quality (Lahav, 1995). Excessive nitrogen fertilization also increases the nutrient loss into the environment by leaching, denitrification and volatilization (Follett, 2001). These losses have the potential of disrupting the environment. To ameliorate this problem, Lorenz (1978) recommended that nitrogen fertilization should be kept to the lowest level that is consistent with an optimum yield.

Nitrogen fertilization in banana has been studied in combination with that of other nutrients and under different agroenvironments. Bhangoo et al. (1962) reported that banana planted on a low fertility acid soil in Honduras responded to a nitrogen application rate of 312 $\mathrm{kg} / \mathrm{ha}$ per year mixed with $62 \mathrm{~kg} / \mathrm{ha}$ of phosphorus and $133 \mathrm{~kg} / \mathrm{ha}$ of potassium. Bunch weight and fruit quality were significantly increased when compared to those with a similar nitrogen rate alone and the zero fertilizer control. Tuyford and Walmsley (1973, 1974a, 1974b) determined dry matter production and nutrient composition and uptake in the Robusta banana planted at various sites throughout the Windward Islands. They estimated that in order for an intensively managed banana plantation to produce 50 tons of fruits per hectare it needed to be fertilized with $448 \mathrm{~kg} / \mathrm{ha}$ of nitrogen the first year, assuming no losses from leaching and fixation (Tuyford and Walmsley, 1974c).

Nitrogen uptake in the Grand Nain banana cultivar grown on a local highly weathered soil during two crop harvests was determined to be $276 \mathrm{~kg} / \mathrm{ha} / \mathrm{crop}$ (Irizarry et al., 1988). After estimating the amount of nitrogen expected to be remobilized from older senescing plant tissues (mother plant) to new tissues (suckers), and its availability from the soil through the recycling of plant residues and subsequent mineralization, the authors recommended the application of about $390 \mathrm{~kg} / \mathrm{ha}$ of nitrogen per crop. This estimate assumed a $50 \%$ loss of the nutrient when applied in inorganic forms. This recommendation has been locally implemented (Agric. Exp. Sta., 1995). However, we have frequently observed that in seven-month-old commercial banana plantations the nitrogen concentration in the lamina of the third uppermost open leaf ranged between 3.30 and $4.00 \mathrm{~g} / \mathrm{kg}$. This concentration is excessively higher than the critical concentration of $2.6 \mathrm{~g} / \mathrm{kg}$ suggested by Lahav and Turner (1983).

The objective of this study was to re-evaluate the nitrogen fertilization recommendation for banana grown on a highly weathered soil. 


\section{MATERIALS AND METHODS}

A banana (Musa acuminata, AAA) fertilizer experiment was conducted between 20 June 1996 and 12 October 1999 at the Corozal Substation of the University of Puerto Rico Agricultural Experiment Station. The substation is located in the north-central region $\left(18^{\circ} 20^{\prime} \mathrm{N}\right.$, $66^{\circ} 18^{\prime} \mathrm{E}$ ) at an elevation of about $195 \mathrm{~m}$.

The experiment was conducted under rainfed conditions. Throughout the experiment, the mean monthly rainfall was $159.4 \mathrm{~mm}$ and evaporation $122.5 \mathrm{~mm}$, with typical fairly well defined dry periods occurring during the months of February, March, April, June and July of each year. Mean monthly minimum and maximum temperatures were 19.5 and $30.4^{\circ} \mathrm{C}$, respectively.

The soil type is a Corozal clay, a typical Ultisol (clayey, mixed isohyperthermic Aquic Haplohumults). Relevant chemical properties in the top 20-cm soil layer were $\mathrm{pH}, 4.7$; extractable phosphorus (Bray method 2), $4.0 \mathrm{mg} / \mathrm{kg}$; and $1.2,3.6,0.7$ and $2.5 \mathrm{cmol}(+) / \mathrm{kg}$ of exchangeable potassium, calcium, magnesium and aluminum, respectively. Total soil nitrogen was $0.2 \%$ and organic matter $3.4 \%$. The soil was strip-plowed twice to a depth of about $25.4 \mathrm{~cm}$ and a width of $1.2 \mathrm{~m}$. Ground limestone was applied between plowings at the rate of $5.6 \mathrm{t} / \mathrm{ha}$ to raise the soil $\mathrm{pH}$ to about 5.3. Because of the use of high amounts of acid-forming fertilizer compounds and the low magnesium content of the soil, the experiment was limed two more times at the rate of $4 \mathrm{t} / \mathrm{ha}$ during growth of the first and second ratoon crops.

Corms of the Grand Nain cultivar weighing about $2 \mathrm{~kg}$ each were used as planting material. At planting, $24 \mathrm{~g}$ of phosphorus as triple superphosphate was placed under the propagating corms.

Five nitrogen rates $(0,85,170,255$ and $340 \mathrm{~kg} / \mathrm{ha} / \mathrm{crop})$ were arranged in a randomized complete block design with three replications. The experimental plots consisted of three strip-cultivated rows of seven plants each. The plants were spaced at $2.90 \mathrm{~m}$ between single rows and $1.52 \mathrm{~m}$ apart in the row, resulting in about 2,268 plants per hectare. The experimental plots were separated by guard plants and ditches to prevent cross contamination of the fertilizer treatments, and the whole experiment was surrounded by a double row of guard plants. The nitrogen treatments were applied with $24.4 \mathrm{~kg} / \mathrm{ha}$ of phosphorus, $651.7 \mathrm{~kg} / \mathrm{ha}$ of potassium and a minor element mixture containing $22.7 \mathrm{~kg} / \mathrm{t}$ of fertilizer. The sources of nitrogen, phosphorus and potassium were ammonium sulfate, triple superphosphate and potassium chloride, respectively. Fertilizer was first applied two and a half months after planting and every three months thereafter. Between the fertilizer treatments all plants in the plant crop received an application of magnesium 
as magnesium sulfate at the rate of $55 \mathrm{~kg} / \mathrm{ha}$. This amount was doubled in subsequent crops to correct a severe magnesium deficiency. The fertilizer was applied in a circular band around the base of the plants.

Foliage diseases, soil-borne pathogens, and weeds were controlled by following recommended cultural practices (Agric. Exp. Sta., 1995). Plants were subjected to a desuckering program five months after planting to maintain in each clump the mother plant and two ratoon suckers. All plant residues generated by this and other agronomic practices were removed from the experimental plots.

The experiment lasted 40 months. Eight plant biomass samplings were conducted, and three crops were harvested. The first biomass sampling for the plant crop was made eight months after planting; it took 16 months for this crop to complete the planting-to-harvest cycle. Thereafter, biomass samplings were conducted every four months, thus three samplings per crop. However, the last biomass sampling of the first ratoon was canceled after a number of plants were destroyed by hurricane "Georges." During biomass sampling, random plants in each experimental plot were dug up and separated into leaf-lamina, leafmidrib and petiole, pseudostem, corm, root and bunch. Before biomass sampling, a composite leaf-lamina sample was taken from the third uppermost open leaf of all experimental plants in each treatment.

For each biomass sampling, green and oven-dry weights of the various plant organs were obtained. Sub-samples from these and the composite samples of the leaf-laminas were dried, ground, sieved through a 20-mesh screen and analyzed for nitrogen, phosphorus, potassium, calcium, magnesium, iron, manganese and zinc. Nitrogen was determined by the micro-Kjeldahl method; phosphorus, colorimetrically; and potassium, calcium, magnesium, iron, manganese and zinc by the Dry-Ashing Method after digestion with $33 \%$ hydrochloric acid. All cations were determined by atomic absorption spectroscopy. Total nitrogen uptake and total dry matter production were calculated by using the product of the dry matter weight and the nutrient concentration in the various plant organs.

At flowering, pseudostem height was measured from the base of the plant to the point of bunch-emergence; pseudostem diameter, at about one meter above ground level. The number of functional leaves was also recorded at this time. Two weeks later the false hand and the male floral bud were removed from the immature bunch, and the latter was covered with a polyethylene bag. Bunches were harvested about 110 days after flowering. At harvest, the bunch marketable weight (total bunch weight minus rachis weight) and the number of hands and fruits per bunch was recorded. The bunch mean fruit weight was determined, and the number of functional leaves was recorded again. In the plant crop and two 
ratoons, data were obtained on plant and bunch traits, total nitrogen uptake, total dry matter production, nutrient concentration in the leaflamina of composite plants four months before harvest, and bunch weight at harvest. The data were statistically analyzed by means of the ANOVA procedure and regression analysis (SAS, 1987). Only coefficients at $\mathrm{P} \leq 0.05$ were considered statistically significant.

\section{RESULTS AND DISCUSSION}

Nitrogen rates did not have a significant effect on plant pseudostem height and diameter at the time of flowering (data not shown). However, plants in the first ratoon (R1) developed significantly taller $(2.4 \mathrm{~m})$ and thicker $(17.5-\mathrm{cm})$ pseudostems than those of the plant crop (PC) and the second ratoon (R2). Nitrogen rate and crop had no significant effect on number of functional leaves (data not shown). Mean number of functional leaves was 12.5 at flowering and 8.8 at bunch harvest.

Crop had no significant effect on bunch traits, but nitrogen rate significantly affected bunch marketable weight, total yield, and number of hands and fruits per bunch. The highest bunch weight $(25.2 \mathrm{~kg})$ and maximum yield response $(57,060 \mathrm{~kg} / \mathrm{ha} / \mathrm{crop})$ were obtained with a nitrogen application of about $240 \mathrm{~kg} / \mathrm{ha} / \mathrm{crop}$ (Figure 1a, b). This amount is $150 \mathrm{~kg} / \mathrm{ha}$ less than the rate previously estimated by Irizarry et al. (1988), and $208 \mathrm{~kg} / \mathrm{ha}$ less than the amount proposed by Tuyford and Walmsley (1974c) to produce a similar high yielding banana crop. Number of hands and fruits per bunch increased linearly with increments in nitrogen rates (Figure $2 \mathrm{a}, \mathrm{b}$ ). However, nitrogen rate and crop had no significant effect on the bunch mean fruit weight (data not shown). Since the fertilizer treatments had no significant effect on bunch mean fruit weight, the additional fruits per bunch produced with the maximum nitrogen rate apparently were of smaller size and did not contribute to an increase in bunch weight in excess of the estimated nutrient application rate of $240 \mathrm{~kg} / \mathrm{ha}$.

There was a significant interaction between fertilizer rate and crop for total nitrogen uptake, total dry matter production, and nitrogen concentration in the leaf-lamina four months before bunch harvest. Total nitrogen uptake and total dry matter production increased linearly with increments in nitrogen rates in the PC and R2. Except for the nitrogen taken up in the $0 \mathrm{~kg} / \mathrm{ha}$ fertilizer treatment, both total nitrogen uptake and total dry matter production were always significantly higher in the R2 than in the PC (Figure 3a, b). Since the maximum yield $(57,060 \mathrm{~kg} / \mathrm{ha})$ for all crops was obtained with a nitrogen application of about $240 \mathrm{~kg} / \mathrm{ha}$ (Figure $1 \mathrm{~b}$ ), the excess 19 and $34 \mathrm{~kg} / \mathrm{ha}$ of nitrogen taken up by the $\mathrm{PC}$ and the $\mathrm{R} 2$, respectively, with the applica- 


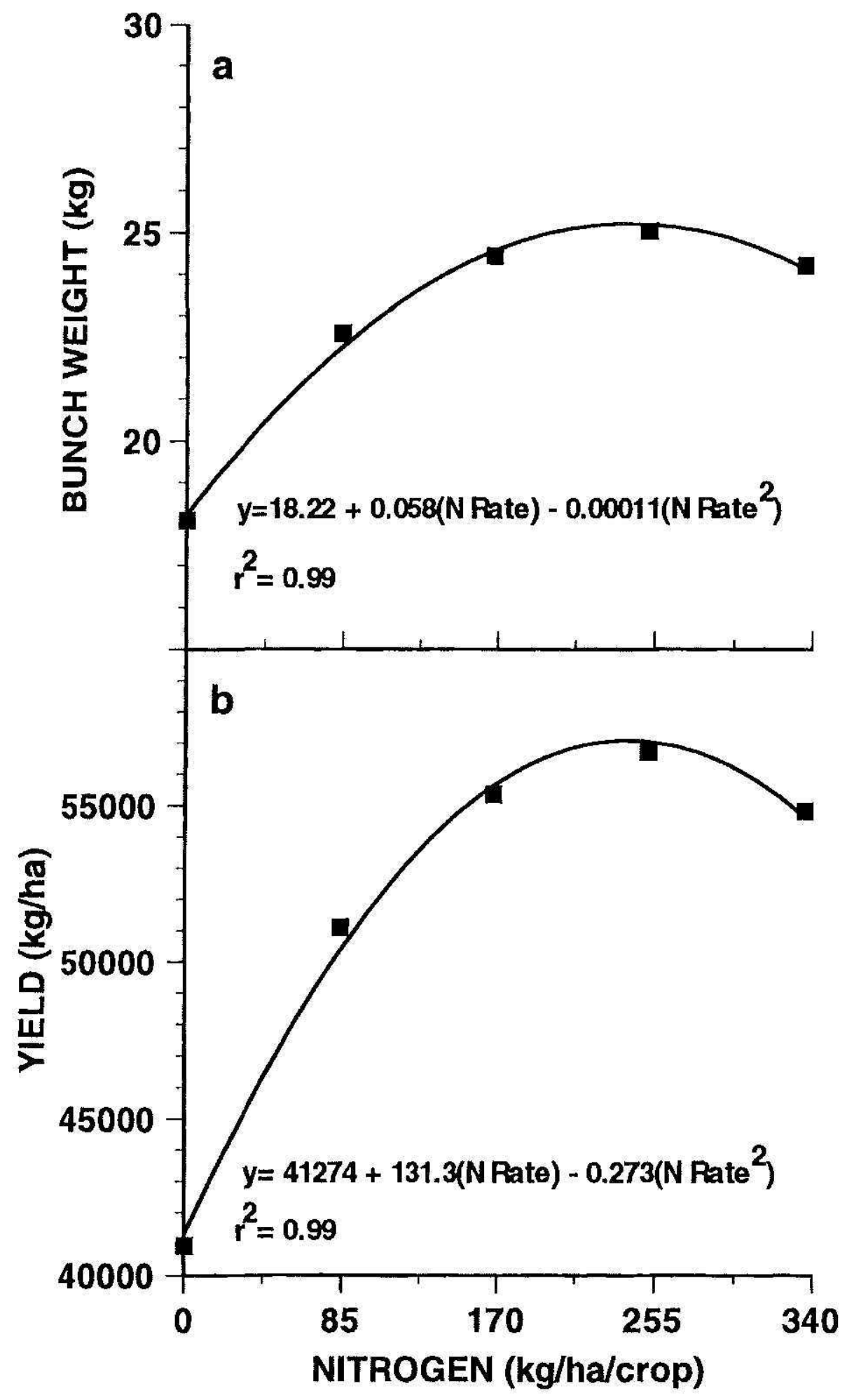

FrgURE 1. Mean bunch weight (a) and yield per hectare (b) as influenced by the application of five nitrogen rates in the plant crop and two ratoons of banana grown on a highly weathered soil. 


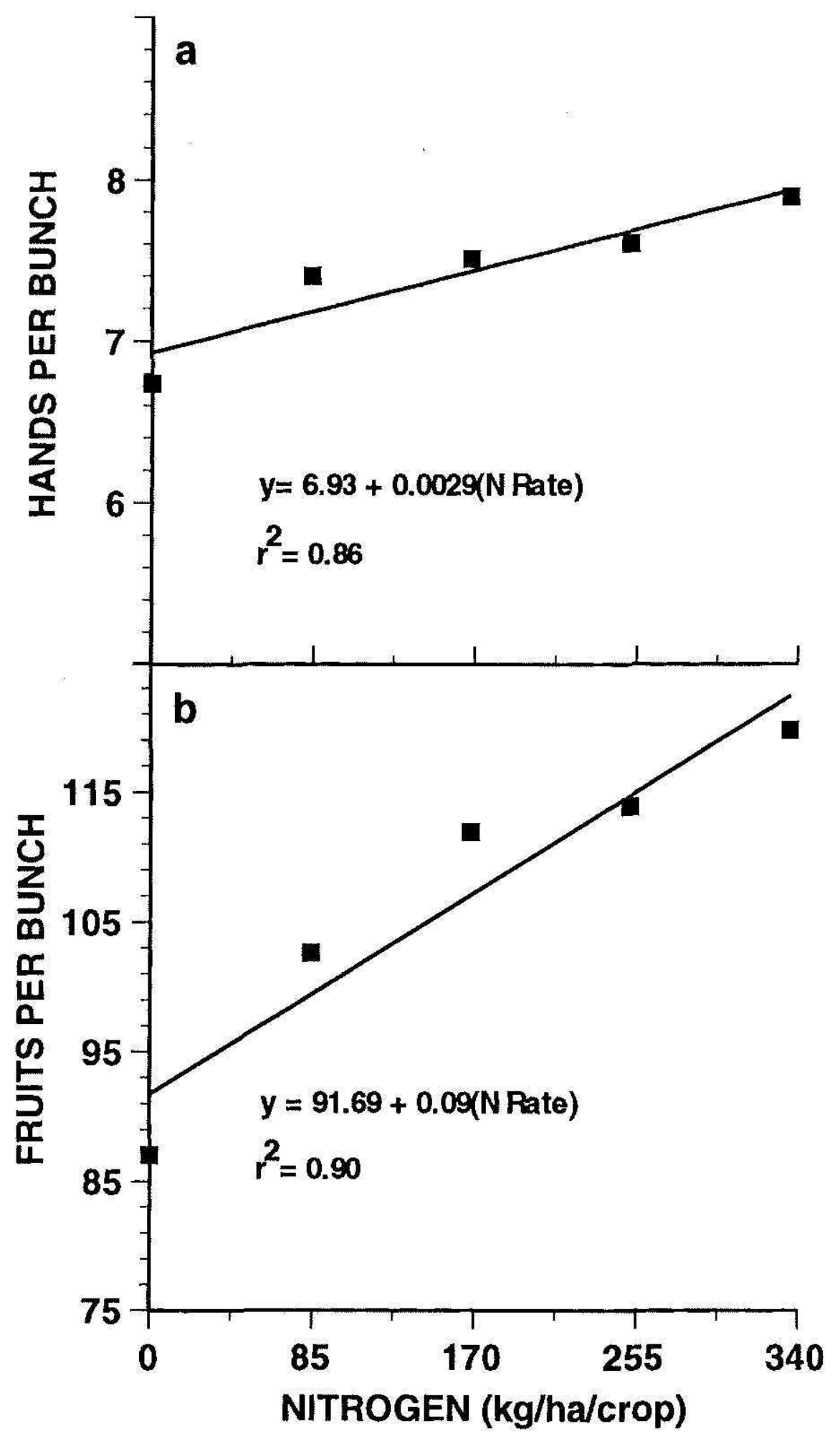

Figure 2. Mean number of hands (a) and fruits per bunch (b) as influenced by the application of five nitrogen rates in the plant crop and two ratoons of banana grown on a highly weathered soil. 


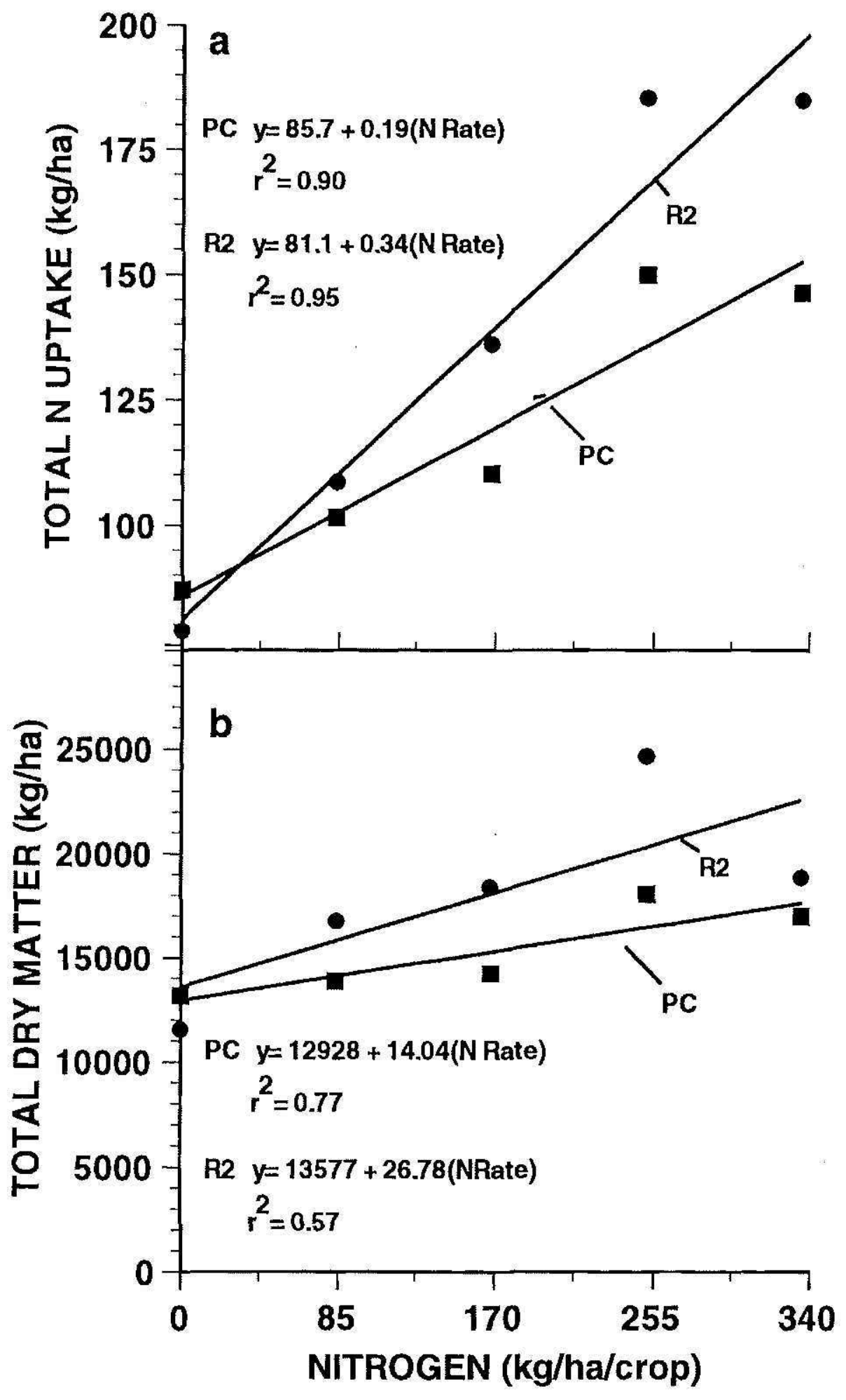

FIGURE 3. Total nitrogen uptake (a) and dry matter production (b) in the plant crop (PC) and second ratoon crop (R2) as influenced by the application of five nitrogen rates in banana grown on a highly weathered soil. 
tion of $340 \mathrm{~kg} / \mathrm{ha}$ of nitrogen (Figure $3 \mathrm{a}$ ) resulted in the production of a surplus of dry matter that ranged between 1,404 and $2,678 \mathrm{~kg} / \mathrm{ha}$ (Figure $3 b$ ). These findings suggest a luxury consumption of nitrogen in banana grown on highly weathered soils. This assumption is strongly supported by previously reported data (Irizarry et al., 1988). In that study the total nitrogen uptake and total dry matter production were 37 and $26 \%$, respectively, higher than in this study, but the marketable yield was about the same, $55,500 \mathrm{~kg} / \mathrm{ha}$. In the previous experiment (Irizarry et al., 1988) the plants were grown with supplemental irrigation and apparently this management practice resulted in a higher luxury consumption of nitrogen. According to Munson and Nelson (1973), optimal soil moisture increases the release of nitrogen and other nutrients from soil organic matter.

Nitrogen concentration in the leaf-lamina four months before bunch harvest increased linearly with increments in nitrogen rates in each crop (Figure 4). Regardless of the nitrogen rate, a significantly higher nutrient concentration was always obtained in the R1 crop. Except for the 0 and $85 \mathrm{~kg} / \mathrm{ha}$ fertilizer rates, the nitrogen concentration was also significantly higher in R2 than in the PC. Since no significant yield increase was obtained above a nitrogen application of $240 \mathrm{~kg} / \mathrm{ha}$, we suggest that the near-optimum nitrogen concentration in the leaf-lamina of a banana plant grown on a highly weathered soil under rainfed conditions should be between 2.75 and $2.85 \mathrm{~g} / \mathrm{kg}$ four months before bunch harvest. Brown (1970) considered a nutrient to be in a luxury state when the nutrient supply and the concentration in the plant surpass the point where the optimum yield response occurs.

The $240 \mathrm{~kg} / \mathrm{ha} / \mathrm{crop}$ nitrogen rate can be supplied by modifying the previous fertilizer recommendation for banana grown on Ultisols (Irizarry et al., 1988). This amount can be provided by applying about $3,000 \mathrm{~kg} / \mathrm{ha} / \mathrm{crop}$ of a 8-2-30-3 $\left(\mathrm{N}, \mathrm{P}_{2} \mathrm{O}_{5}, \mathrm{~K}_{2} \mathrm{O}, \mathrm{MgO}\right)$ fertilizer mixture.

In this experiment, all plant residues were removed from the plots during weeding, biomass sampling, and bunch harvest. However, it is expected that under a conventional banana management system some of the nutrients contained in the corm of the mother plants will be remobilized to the ratoon suckers and those from other plant residues recycled to the soil. Those recycled residues will become available to the ratoon plants after mineralization. At the time of bunch harvest, the amount of nitrogen that was estimated to be remobilized and recycled was $81 \mathrm{~kg} / \mathrm{ha}$ in the $\mathrm{PC}$ and $98 \mathrm{~kg} / \mathrm{ha}$ in the $\mathrm{R} 2$ with the nutrient application of $240 \mathrm{~kg} / \mathrm{ha} / \mathrm{crop}$. Of these amounts about $25 \%$ was expected to be remobilized and $75 \%$ recycled. The rate of nitrogen mineralization in some Ultisols using a 30 -week soil incubation period has been estimated to be in the range of 28 to $78 \mathrm{~kg} / \mathrm{ha} /$ year (Stanford and Smith, 


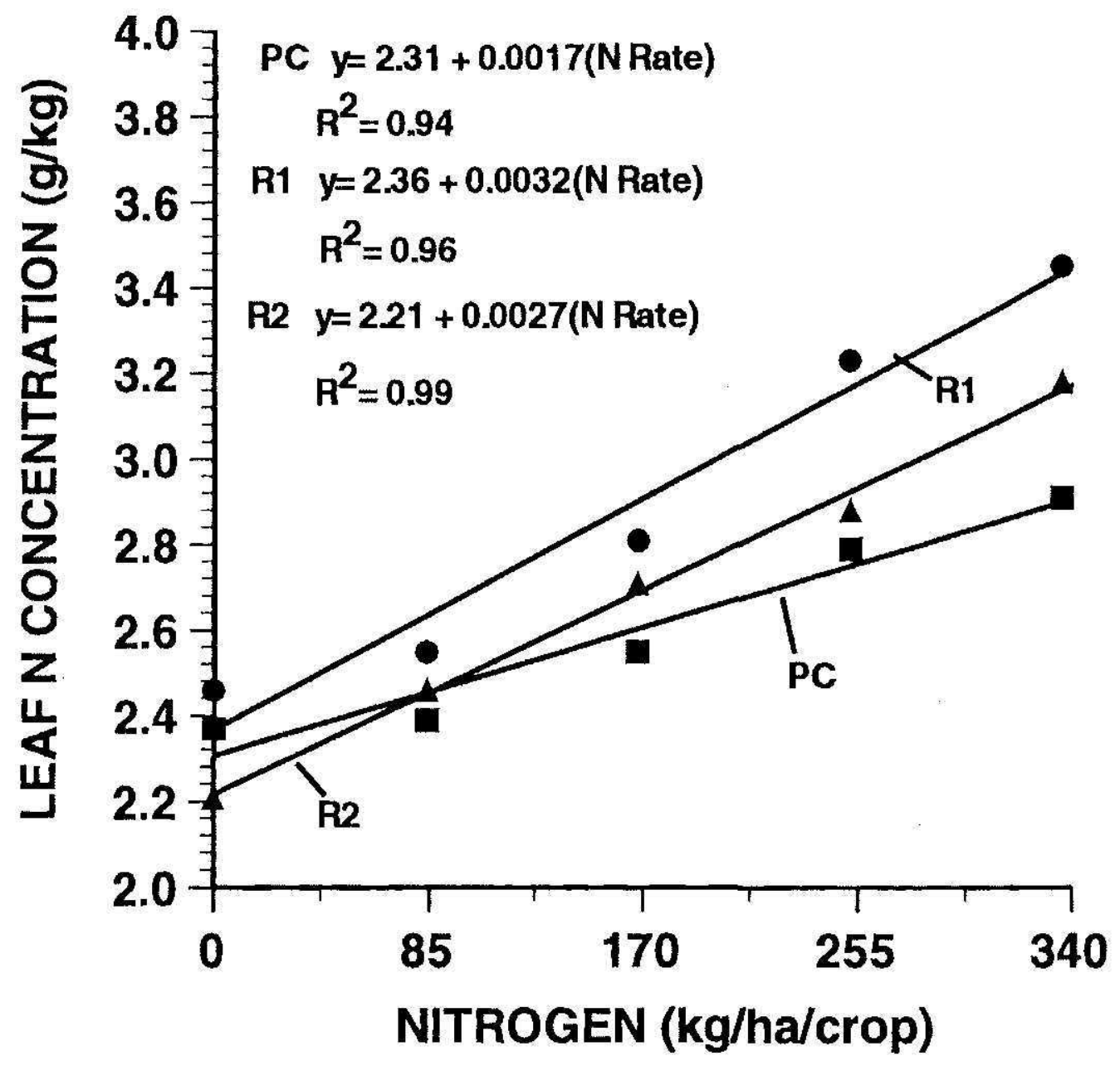

FIGURE 4. Leaf nitrogen concentration in the plant crop (PC) and two ratoon crops (R1, R2) as influenced by the application of five nitrogen rates in banana grown on a highly weathered soil.

1972). However, the nitrogen mineralization rate is affected by many soil and climatic factors and decreases gradually with an increase of the incubation period. We did not consider nitrogen mineralization in adjusting nitrogen fertilization of the banana ratoons because in this experiment there was no significant yield difference between crops, and most local commercial plantations are renewed after the second or third ratoon harvest. However, under long-term banana cultivation the nitrogen-supplying capacity of the soil should be considered for a more efficient use in the ratoon crops.

\section{LITERATURE CITED}

Agricultural Experiment Station, 1995. Conjunto Tecnológico para la Producción de Plátanos y Guineos. Univ. P.R., Río Piedras, PR. Publ, 97. 
Bhangoo, M. S., F. G. Altman and M. L. Karon, 1962. Investigations on the Giant Cavendish banana. I. Effect of nitrogen, phosphorus and potassium on fruit yield in relation to nutrient content of soil and leaf tissue in Honduras. Trop. Agric. (Trinidad) 39(2):189-201.

Brown, J. R., 1970. Plant analysis. Missouri Agric. Exp. Sta. Bull. SB881.

Follett, R. F, 2001. Innovative ${ }^{15} \mathrm{~N}$ microplot research techniques to study nitrogen use efficiency under different ecosystems. In: Mills, H. A. (ed.). Communications in Soil Science and Plant Analysis 32(7,8):951-979.

Irizarry, H., E. Rivera and J. Rodríguez, 1988. Nutrient uptake and dry matter composition in the plant crop and first ratoon of the Grand Nain banana grown on an Ultisol. J. Agric. Univ. P.R. 72(3):337-351.

Lahav, E. and D. W. Turner, 1983. Fertilizing for high yield banana. International Potash Institute, Bull. No. 7, Berne, Switzerland.

Lahav, E., 1995. Banana nutrition. In: Gowen, S. (ed.). Bananas and plantains. Chapman and Hall, New York, NY. 258-316.

Lorenz, O. A., 1978. Potential nitrate levels in edible plant parts. In: Nielsen, D. R. and J. G. MacDonald (eds.). Nitrogen in the environment. Vol. 2. Soil-plant-nitrogen relationships. Academic Press, New York, San Francisco, London. 201-252.

Munson, R. D. and W. L. Nelson, 1973. Sampling, handling, and analyzing plant tissue samples. In: Walsh, L. M. and J. D. Beaton (eds.). Soil testing and plant analysis (revised ed.). Soil Sci. Soc. Amer. Madison, WI. 223-248.

Robinson, J. C., 1996. Banana and plantains. CAB International, Wellingford, U.K.

SAS Institute, 1987. SAS/STAT: Guide for personal computers. Version 6. Cary, NC.

Stanford, G. and S. J. Smith, 1972. Nitrogen mineralization potentials of soils. Soil Sci. Soc. Amer. Proc. 36:465-472.

Turner, D. W. and B. Barkus, 1974. The effect of season, stage of plant growth and leaf position on nutrient concentrations in banana leaves on a krasnozem in New South Wales. Aust. J. Exp. Agric. Anim. Husb. 14:112-117.

Tuyford, I. T. and D. Walmsley, 1973. The mineral composition of the Robusta banana plant. I. Methods and plant growth studies. Plant and Soil 39:227-243.

Tuyford, I. T. and D. Walmsley, 1974a. The mineral composition of the Robusta banana plant. II. The concentration of mineral constituents. Plant and Soil 40:459-470.

Tuyford, I. T. and D. Walmsley, 1974b. The mineral composition of the Robusta banana plant. III. Uptake and distribution of mineral constituents. Plant and Soil 41:471-491.

Tuyford, I. T. and D. Walmsley, 1974c. The mineral composition of the Robusta banana plant. IV. The application of fertilizers for high yields. Plant and Soil 41:493-508. 